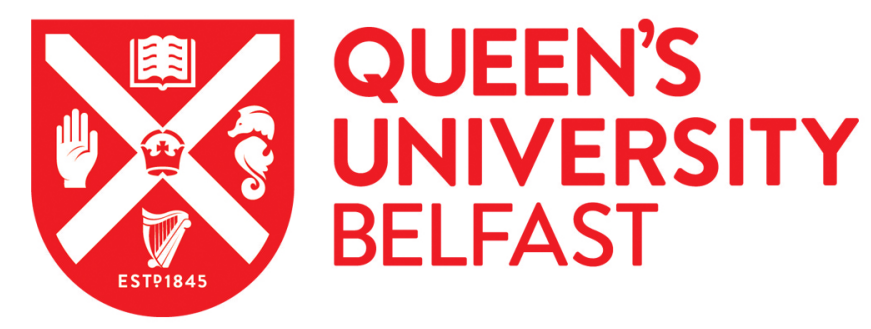

\title{
Charlemagne, Common Sense, and Chartism: how Robert Blakey wrote his History of Political Literature
}

Mathieson, S. (2019). Charlemagne, Common Sense, and Chartism: how Robert Blakey wrote his History of Political Literature. History of European Ideas. https://doi.org/10.1080/01916599.2019.1599409

\author{
Published in: \\ History of European Ideas
}

\section{Document Version:}

Peer reviewed version

Queen's University Belfast - Research Portal:

Link to publication record in Queen's University Belfast Research Portal

Publisher rights

(c) 2019 Informa UK Limited, trading as Taylor \& Francis Group. This work is made available online in accordance with the publisher's policies. Please refer to any applicable terms of use of the publisher.

\section{General rights}

Copyright for the publications made accessible via the Queen's University Belfast Research Portal is retained by the author(s) and / or other copyright owners and it is a condition of accessing these publications that users recognise and abide by the legal requirements associated with these rights.

Take down policy

The Research Portal is Queen's institutional repository that provides access to Queen's research output. Every effort has been made to ensure that content in the Research Portal does not infringe any person's rights, or applicable UK laws. If you discover content in the Research Portal that you believe breaches copyright or violates any law, please contact openaccess@qub.ac.uk. 


\section{Charlemagne, Common Sense, and Chartism: how Robert Blakey wrote his History of Political Literature.}

This article examines the life and works of Robert Blakey, author of the first English-language history of political thought. Studies of Blakey have typically concentrated on one aspect of his life, whether as an authority on field sports or as an historian of philosophy. However, some of Blakey's lesser-known ventures, particularly his early Radical politics, his hagiographies, and his attempts to write a biography of Charlemagne, heavily influenced his more famous works. Similarly, Blakey's upbringing in a Calvinist tradition, rooted in the Scottish School of Common Sense philosophy helps makes sense of his philosophical and theological commitments, yet has been largely ignored. This article provides a sketch of Blakey's life, tying these disparate strands together, and explaining their influence upon, and relevance to, the first history of political philosophy.

Keywords: History of political thought; Chartism; Robert Blakey; Common Sense; history of philosophy.

\section{Introduction}

Robert Blakey was the author of the first systematic history of political thought, his History of Political Literature. Yet to posterity, Blakey is perhaps best known as an authority on game sports, particularly fly-fishing. ${ }^{1}$ Occasionally, Blakey appears as a peripheral figure, in a foreword or footnote acknowledging his contribution to fields such as political journalism, Common Sense philosophy, Chartism, or angling. Some historians of political thought have nevertheless highlighted Blakey's authorship of the 'first genuine textbook' in that field and his role in the establishment of the history of political thought as a 'disciplinary genre'. ${ }^{2}$ However, while Blakey's authorship of the

\footnotetext{
1 'Yesterday's New Books', Standard (London), 24 Nov. 1898; Anonymous, letter to the editor, Country Gentleman: A Sporting Gazette and Agricultural Journal, 6 Nov. 1886; 'The Sportsman's Library', Baily's Magazine of Sports and Pastimes, 1 Jan. 1899, 39; Keith Elliot, 'Fishing Lines: Hooked on Musical Bait', Independent, 25 Sept. 1994.

${ }^{2}$ Siep Stuurman, 'The Canon of the History of Political Thought: Its Critique and a ProposedAlternative', History and Theory 39, no. 2 (2000): 149; James Farr, 'The History of
} 
first history of political thought is well-established, much of the other information about Blakey is incomplete, confused, or misconstrued. ${ }^{3}$ In part, this is due to the wide variety of fields in which Blakey involved himself. Historians have then viewed Blakey through the prism of their own disciplinary interests. He is variously identified as a philosopher, an historian of political thought, a professor at Queen's College Belfast, a radical journalist, or an expert on angling. Blakey was, at various times, and to varying degrees of success, each of these. Yet by considering Blakey in isolation, much vital context is missed. Blakey's philosophy can be much better understood when considered alongside his religious and political views. Similarly, his religious and political views reflect the circumstances of his upbringing and early career. Further, Blakey presented a partial, sanitised account of his own life in his Memoirs, and consequently his biography must be reconstructed from correspondence, newspaper articles, and archival material. For instance, the Memoirs contain no mention of Blakey's dismissal from Queen's, and skip from April 1850, after his first term had concluded, to January 1851. Obituaries of Blakey, and several biographical entries, including his original entry in the Dictionary of National Biography, have followed the Memoirs and give the impression that Blakey taught at Queen's for the remainder of his career; certainly, none mention his being dismissed. ${ }^{4}$ Roger Hawkins's entry for the Oxford Dictionary of National Biography has remedied

Political Thought as Disciplinary Genre' in The Oxford Handbook of Political Theory, ed. John Dryzek, Bonnie Honig, and Anne Phillips (Oxford: Oxford University Press, 2006), 226.

${ }^{3}$ Stuurman, 'The Canon of the History of Political Thought': 149-52; Paul Kelly, 'Contextual and Non-Contextual Histories of Political Thought', in The British Study of Politics in the Twentieth Century, ed. Jack Hayward, Brian Barry, and Archie Brown (Oxford: Oxford University Press, 2003), 41; Farr, 'The History of Political Thought as Disciplinary Genre' : 226, 231-3; Andrew Vincent, The Nature of Political Theory (Oxford: Oxford University Press, 2007), 40; David Boucher and Paul Kelly, introduction to Political Thinkers from Socrates to the Present, 2nd ed. (Oxford: Oxford University Press, 2009), 3, 5, 7.

${ }^{4}$ Leslie Stephens (ed.), Dictionary of National Biography, 14 vols (London: Smith, Elder, \& Co., 1885-1900), 2:651-2; Freeman's Journal and Daily Commercial Advertiser, 27 Oct. 1879. 
most of the faults of Blakey and his editor, Henry Miller. ${ }^{5}$ However, a closer reading of the Memoirs alongside press reports, correspondence, and analysis of his writing is still profitable for historians of ideas.

Several historians of political thought have argued that their discipline is taught, broadly speaking, through the use of key texts that contain 'an uncontested, consensual fund of universally accepted truths about politics', with an established canon of great thinkers. ${ }^{6}$ History of Political Literature did not follow, but rather originated, this approach. Blakey used works of political writing to present the story of what he considered to be the timeless truths of politics. In so doing, he established both a framework and a canon that has survived relatively unscathed until the present day. Yet Blakey's idiosyncratic approach has not been fully explored or explained. Through a study of Blakey's life, this article explores his work as a historian of philosophy, and in particular his histories of philosophy of mind and political thought. It also provides an account of Blakey's earlier life, explaining the context in which his own political and philosophical views developed, and how these informed and coloured his approach to the history of philosophy. Most importantly, it demonstrates the continuing influence of his early education, steeped in Calvinist theology, political liberalism, and the Scottish school of Common Sense philosophy, on his later work.

Although Blakey mentions his political career in his Memoirs, its importance is understated compared to his literary efforts. While earlier sections make clear his Radical

\footnotetext{
${ }^{5}$ Roger Hawkins, 2008, 'Blakey, Robert [pseud. Palmer Hackle] (1795-1878), radical and historian of philosophy, Oxford Dictionary of National Biography, (https://doi.org/10.1093/odnb/9780192683120.013.2595) (2 Mar. 2019)

${ }^{6}$ Stuurman, 'The Canon of the History of Political Thought': 147; Boucher and Kelly, Political Thinkers, 3-5.
} 
sympathies, he makes no mention of Chartism, despite being proprietor of the secondlargest Chartist newspaper. Nor does he offer any insight into his political views after his trial for seditious libel. Consequently, it is difficult to paint a coherent picture of Blakey's politics, and particularly their development over time. Indeed, the only constant themes that appear are an emphasis on the importance of education, and a commitment to electoral reform, as Blakey's sole explicit mention of his political system reveals: 'Universal Suffrage, Annual Parliaments, and Election by Ballot'. A recent study of Chartism highlighted the relative success of Blakey's paper, the Northern Liberator, but merely identified Blakey as its proprietor and editor, and does not explain Blakey's wider role, or his political history. ${ }^{8}$ This article traces the development Blakey, from his early years as an orphaned, irregularly schooled hatter and furrier, through his years as a Radical mayor and Chartist publisher, his brief stint as a professor of philosophy, and to his legacy as the first historian of political literature, and demonstrates how one Radical rebranded himself as an upwardly-mobile man of letters, yet continued to promote his political philosophy in his writing.

\section{1795-1832: Blakey's early political history}

Robert Blakey was born on 18 May 1795, in Manchester Lane, Morpeth, Northumberland. At the age of six, the orphaned Blakey was placed in the care of his grandmother, Elizabeth Laws. Laws taught Blakey to read using her favourite books, particularly the Bible. Meanwhile, Blakey's uncle Robertson put him to work in horticulture, which provided Blakey with the funds to acquire his own modest collection of books. Robertson also sent Blakey to a night school during the winter months and took

\footnotetext{
${ }^{7}$ Robert Blakey, Memoirs of Dr Robert Blakey: Professor of Logic and Metaphysics, Queen's College, Belfast, ed. Revd Henry Miller (London: Trübner, 1879), 59.

${ }^{8}$ Malcolm Chase, Chartism: A New Histoy (Manchester: Manchester University Press, 2007), 44, 109
} 
a personal interest in discussing history and theology with his nephew. In 1809, Blakey and Laws moved to Alnwick, where Blakey met three men who would profoundly influence his intellectual development. David Paterson, Alnwick's Presbyterian minister, involved himself in Blakey's education, encouraging him to read and study. Two local tradesmen, Robert Dunn and Thomas Hall, befriended the young Blakey and arranged, with Paterson, for him to receive evening tuition after he finished his day job as a furrier. Dunn and Hall were members of a class of literate, politically-conscious artisans; they introduced Blakey to Radical politics, and shared a love of epic poetry, such as Milton's Paradise Lost. ${ }^{9}$ When Blakey returned to Morpeth in 1815 , he retained those interests in literature and politics while establishing himself as furrier and hatter, becoming a northern example of the radical London artisans described by Iorwerth Prothero. ${ }^{10}$ According to Blakey, Dunn and Hall were 'ardent political reformers of a very advanced school', who frequently read and discussed the radical newspapers of their day, including the Tyne Mercury and William Cobbett's Political Register. ${ }^{11}$ Both were also, as Blakey would later be, local craftsmen, who maintained an interest in literature, religious thought, and radical politics. While at Alnwick, Blakey sent some letters to the Tyne Mercury, but it was not until his return to Morpeth in 1815 that he began correspondence in earnest, writing on topics such as electoral reform and the abolition of slavery for the local press, the Register, and for the radical Black Dwarf in London. ${ }^{12}$ While Blakey does not describe in detail his early political views beyond suffrage, education, and slavery, it is possible to infer from his reading material some key influences. In addition to the radical press,

\footnotetext{
${ }^{9}$ Blakey, Memoirs, 1-2, 7, 8, 10, 15, 17, 18-21.

${ }^{10}$ Iorwerth Prothero, Artisans and Politics in Early Nineteenth-Century London: John Gast and his Times (London: Dawson, 1979); Blakey, Memoirs, 43-4.

${ }^{11}$ Blakey, Memoirs, 19.

12 Ibid., 50; Laurel Brake, Marysa Demoor, and Margaret Beetham (eds.), Dictionary of Nineteenth-Century Journalism in Great Britain and Ireland (London: Academia Press and the British Library, 2009), 60.
} 
Blakey mentions that he enjoyed reading political works by John Locke, Montesquieu, Thomas Paine and William Godwin. ${ }^{13}$ This suggests an early interest in constitutional reform, as all four advocated separation of powers and limited government. It also hints at Blakey's belief that legitimate political authority was ultimately derived from the people, another common theme in works by all four. Locke, whose works Blakey held in particular esteem, also represents the only obvious link between his more conservative philosophical views and his politics.

While Blakey struggled to establish himself as a political commentator, his standing in the local business community continued to grow. In 1820, Blakey delivered a speech on the Queen Caroline affair to Earl Grey, as 'head of the deputation of the tradesmen of town'. ${ }^{14} \mathrm{He}$ also became a member of the Mitford Association for the Prosecution of Felons in $1824 .{ }^{15}$ In the absence of a police force or public prosecutor, private citizens were expected to bring suits themselves, which was a costly business that deterred many victims from seeking redress. To remedy this, local property holders arranged themselves into associations which sought to reward the apprehension, and fund the prosecution, of felons, thus discouraging attacks on their businesses. ${ }^{16}$ Blakey merged his interests in business and politics when a local working-man's association, the Morpeth Mechanical and Scientific Institute, was founded in 1825. Similar organisations, dedicated to the continuing education of manual workers, had begun to spring up across Britain over the preceding two years. The most prominent of these was the London Mechanics Institute, formed in 1823, although similar bodies already existed in Glasgow and Liverpool, and

\footnotetext{
${ }^{13}$ Blakey, Memoirs, 58, 89, 197.

${ }^{14}$ Ibid., 44.

${ }^{15}$ Newcastle Courant, 3 Jan. 1824, 15 Jan. 1825.

${ }^{16}$ Adrian Shubert, 'Private Initiative in Law Enforcement: Associations for the Prosecution of Felons, 1744-1856' in Victor Bailey (ed.) Policing and Punishment in Nineteenth Century Britain (London: Crook Helm, 1981), 26, 30.
} 
Jonathan Rose has persuasively argued that the origins of these groups lie in the mutual improvement societies common during the Scottish Enlightenment. ${ }^{17}$ Blakey was approached by two Newcastle businessmen, John Fenwick and Emerson Chanley, who were interested in forming an institution in Morpeth. After overcoming his initial hesitation, fearing public outcry over popular education and its association with radical politics, Blakey pledged his assistance. He produced a pamphlet on the value of education, a theme he would revisit several times throughout his career, and convened a meeting of local worthies to seek funding, although Blakely noted that he personally kept a low profile, lest his 'very advanced political views' discourage the gentry from contributing. ${ }^{18}$ Nevertheless, Blakey was appointed as a secretary to the institution, which had as its patron Lord Morpeth, to whom Blakey would dedicate his Essay on Logic in 1834. ${ }^{19}$ Blakey was also entrusted with the procurement of books for the institute's library, acquiring several hundred volumes in Edinburgh. ${ }^{20}$ Intriguingly, Blakey's Memoirs make no subsequent reference to the organisation that he was instrumental in founding. However, Blakey did donate a copy of his Historical Sketch of Logic to its library in $1851 .^{21}$

Throughout the 1820 s and early 1930 s, Blakey continued to be a moderately successful local tradesman, well-versed in radical political thought, who became increasingly involved in local political life. Blakey's Memoirs also suggest that he developed antiauthoritarian, somewhat contrarian personality developed during this period, based on the

\footnotetext{
${ }^{17}$ Thomas Kelly, George Birkbeck: Pioneer of Adult Education (Liverpool: Liverpool University Press, 1957), 80; Jonathan Rose, The Intellectual Life of the British Working Classes (New Haven, CT: Yale University Press, 2010), 58-72.

${ }_{18}^{18}$ Blakey, Memoirs, 57.

19 'Local occurrences', Newcastle Magazine, Apr. 1825.

${ }^{20}$ Blakey, Memoirs, 57-8.

${ }^{21}$ Morpeth Herald, 26 Jan. 1907.
} 
examples of leading members of the radical press. For instance, Blakey wrote admiringly of how Thomas Wooler, proprietor of the Black Dwarf, had conducted himself during a libel trial in $1817 .{ }^{22}$ Similarly, when William Cobbett was charged with seditious libel for a series of measured but sympathetic articles on the Captain Swing riots, he undertook his own defence, greatly embarrassing members of the Whig government in court. ${ }^{23}$ Blakey was particularly taken with Cobbett's actions and organised a local meeting which sent a letter of support during the trial. ${ }^{24}$ After Cobbett was acquitted, Blakey visited him in London, striking up both a friendship and correspondence. Blakey deeply admired Cobbett, describing him as 'one of the most distinguished literary and political characters which ever adorned this or any other country', and included several communications from Cobbett in his Memoirs. When Cobbett undertook a lecture tour of the North East in September 1832, he stayed with Blakey in Morpeth and spent several hours discussing politics and religion. Blakey's appreciation for Cobbett's rhetorical abilities is evident in his account of the tour, where he mentions Cobbett's 'good-natured facetiousness, and sarcasm' ${ }^{25}$ Cobbett also refers to the visit in his memoir of the tour, without naming Blakey, simply referring to 'my friend', although he does note that he enjoyed Blakey's 'most sensible conversation'. ${ }^{26}$ Cobbett also clearly felt that Blakey was a capable writer and organiser: he wrote to Blakey, urging him to arrange local meetings and petitions against the proposed $£ 10$ franchise requirement in the upcoming Great Reform Act. $^{27}$

\footnotetext{
${ }^{22}$ Blakey, Memoirs, 29-30.

${ }^{23}$ Cobbett's Weekly Political Register, 4 and 11 Dec. 1830; James Sambrook, William Cobbett (London: Routledge, 1973), 173-4.

${ }^{24}$ Cobbett's Weekly Political Register, 16 Jul. 1831.

${ }^{25}$ Blakey, Memoirs, 68, 53-4, 59-64, 87, 69.

${ }^{26}$ William Cobbett, Cobbett's Tour in Scotland, and in the Four Northern Counties of England: in the Autumn of the Year 1832 (London: Mills, Jowett, and Mills, 1833), 56.

${ }^{27}$ Blakey, Memoirs, 55; Cobbett's Weekly Political Register, 30 Jun. 1832.
} 
The Great Reform Act was pivotal in Blakey's political life, forming a bridge between his involvement in primarily local interests and the wider agitations for political reform that were sweeping England, and spawning political associations. At a meeting in a Newcastle music hall on 27 June 1831, the Northern Political Union was formed, and pledged to support the democratic ideals that lay at the heart of demands for electoral reform. Blakey's friend Thomas Doubleday, with whom he would later partner to publish the Northern Liberator, was the union's secretary, while Blakey made a speech at the inaugural meeting and was elected to its council for two years. ${ }^{28}$ Through his involvement with the Northern Political Union and correspondence with Cobbett, Blakey moved from being a politically-aware commentator and tradesman who primarily supported local efforts at improvement and reform to an active participant in wider political life. However, Blakey had not abandoned his philosophical interests; 1831 also saw the publication of his first book, An Essay Shewing the Intimate Connexion between our Notions of Moral Good and Evil, and our Conceptions of the Freedom of the Divine and Human Wills. ${ }^{29}$

\section{1832-41: early philosophical works, Radical mayor, and the Northern Liberator.}

When the Great Reform Act successfully passed in 1832, the Northern Political Union was dissolved. Blakey turned to writing in order to fill his time, producing an essay on logic alongside a two-volume history of moral philosophy, History of Moral Science. ${ }^{30}$

\footnotetext{
${ }^{28}$ The Objects and Rules of the Northern Political Union: Passed at a Meeting held in the Music Hall, Newcastle upon Tyne, on Monday, 27th June 1831 with the Declaration of the Council of the Union (Newcastle, 183); The Northern Tribune: A Periodical for the People 1, (Nov. 1854): 324-5; Blakey, Memoirs, 73.

${ }^{29}$ Robert Blakey, An Essay Shewing the Intimate Connexion between our Notions of Moral Good and Evil, and our Conceptions of the Freedom of the Divine and Human Will (Edinburgh: Adam Black, 1831).

${ }^{30}$ Robert Blakey, An Essay Towards an Easy and Useful System of Logic (Edinburgh: James Duncan, 1834); idem., History of Moral Science, 2 vols (Edinburgh: James Duncan, 1833-6).
} 
Moral Science excited more interest than the Essay. It was more widely advertised and several philosophical writers to whom Blakey had sent copies returned favourable correspondence. Sir William Hamilton noted that it supplied 'a desideratum' in English, while Poet Laureate Robert Southey and the author Allan Cunningham also praised Blakey's effort and writing style. ${ }^{31}$ Prominent Scottish divine Thomas Chalmers delivered a lengthy reply, likewise commending Blakey's prose, and his treatment of Hutcheson, but finding fault with his views upon predestination and necessity. ${ }^{32}$ Daniel Dewar, principal of Marischal College, Aberdeen, described it as 'a work of very great merit'. ${ }^{33}$ Press reviews of Moral Science were, however, mixed. The British Critic and Quarterly Theological Review opined that while the work served as a useful introduction to the topic, 'the labours of the author have been almost entirely confined to the expansion of such notes as might be taken down while listening to the lectures of a Professor in some northern seminary'. ${ }^{34}$ The Eclectic Review, meanwhile, praised Blakey's evenhandedness and his reservations about the entirety of Hobbesian morality, but argued that these 'ought surely to have been much stronger'. ${ }^{35}$ There was also a mildly favourable review in The New Monthly Magazine which commended Blakey's ability but noted that much of his biographical information was taken directly from encyclopaedic sources. ${ }^{36}$ In the Monthly Repository, no less an authority than John Stuart Mill delivered an uncompromising review of Moral Science. Mill commended Blakey's even-handed treatment of British thinkers, but criticised his lack of attention to continental authors, accusing him of being 'profoundly ignorant' in this regard. ${ }^{37}$ Mill also correctly identified

\footnotetext{
${ }^{31}$ Morning Chronicle, 19 Jun. 1833, 4 May 1834; Morning Post, 2 Aug. 1833, 10 Mar. 1834, 17 May 1836; Caledonian Mercury, 20 Apr. 1833, 11 May 1834; Blakey, Memoirs, 99, 100-1.

${ }^{32}$ Ibid., 101-2.

${ }^{33}$ Ibid., 235.

${ }^{34}$ British Critic and Quarterly Review 19 (Jan. 1836): 162.

${ }^{35}$ Eclectic Review 11 (Feb. 1834): 138.

${ }^{36}$ New Monthly Magazine and Literary Journal 38 (May 1833): 99-100.

${ }^{37}$ Monthly Repository, 7 (Oct. 1833): 665.
} 
Blakey's tendency to make his own moral considerations the determining factor in whether he accepted an argument. However, Mill insisted that Blakey understood the intent of Voltaire's Candide as being 'written to support the doctrines which are put into the mouth of Pangloss' ${ }^{38}$ Blakey's remarks on the novel, however, are that it was 'written for the express purpose of ridiculing Leibnitz's system', which is the Optimism that Pangloss espouses. ${ }^{39}$ In his later Philosophy of Mind, Blakey also clearly and correctly pointed out the intent of Candide as a riposte to Optimism, and so it appears that Mill was mistaken on this point.

Meanwhile, Blakey continued his interest in active politics. In 1835, electoral reform was again the focus of public debate and Blakey wrote a petition letter to the mayor of Newcastle demanding a meeting of the free burgesses on the matter. ${ }^{40}$ The subsequent passage of the Municipal Corporations Act created in Morpeth, for the first time, a democratic local council, to which Blakey, standing on a Radical platform, was elected. ${ }^{41}$ Blakey remained on the council until 1840, including a year's term as Mayor from November 1836 to 1837 during which he successfully oversaw the foundation of two local corporation schools. ${ }^{42}$ As universal education would not be provided in England until the Elementary Education Act was passed in 1870, it seems that Blakey and the council were several decades ahead of their time. During his mayoral year, however, Blakey's bellicose streak again emerged. In an effort to acquire funding for the schools, he sent a resolution from the council to the local press, calling on the rector of Morpeth, Frederick Ekins, to release the $£ 500$ that had been assigned from parish subscriptions for

\footnotetext{
${ }^{38}$ Ibid., 666.

${ }^{39}$ Blakey, Moral science, ii. 289.

${ }^{40}$ Newcastle Courant, 20 Jun. 1835.

${ }^{41}$ Newcastle Courant, 2 Jan. 1836; Morning Post, 2 Jan. 1836; Morning Chronicle, 1 Jan. 1836.

${ }^{42}$ Newcastle Courant, 12 Nov. 1836; Blakey, Memoirs, 109.
} 
a charity school over twenty years earlier. ${ }^{43}$ When Ekins refused, Blakey convened a local court to try him on an unrelated technicality; a melodramatic attempt to publicly shame the rector into acquiescence, which was ultimately unsuccessful. ${ }^{44}$ Blakey also began a feud with Morpeth's Board of Guardians, who were responsible for administering poor relief under the New Poor Law. The New Poor Law had been passed in 1834, but it was not until 1836 that it was implemented in Northumberland, when Blakey was elected to the Morpeth board. ${ }^{45}$ Blakey was strongly opposed to the New Poor Law and described it as 'despicable and tyrannical' ${ }^{46} \mathrm{He}$ began writing a series of letters, first criticising the cruelty of some members of the board, singling out Sam Donkins, and later the poor law in general. These were compiled and published as Cottage Politics, a reference to Cobbett's Cottage Economics, later that year. ${ }^{47}$ The Board of Guardians were unimpressed with Blakey's criticism, and passed a resolution against him. ${ }^{48}$ Eventually the assistant commissioner of the poor law, Sir John Walsham, became involved, and invited Blakey to meet and discuss his charges. Blakey declined, but, chastened, withdrew most of his accusations against the board. ${ }^{49}$ However, he continued to quarrel with Donkins, who responded by pointing out that Blakey rarely attended meetings. ${ }^{50}$ A series of increasingly acerbic letters were exchanged in the local press between Donkins, Blakey, and George Brumell, clerk of the Morpeth union, before the dispute fizzled out. ${ }^{51}$ Beyond his commitment to education, and his stubborn nature, Blakey's mayoral year

\footnotetext{
${ }^{43}$ Newcastle Standard, 3 Dec. 1836.

${ }^{44}$ Tyne Mercury, 10 Jan. 1837.

${ }^{45}$ Newcastle Chronicle, 1 Oct. 1836.

${ }^{46}$ Newcastle Chronicle, 4 Mar. 1837.

${ }^{47}$ Newcastle Courant, 14 Apr. 1837; Northern Liberator, 30 Dec. 1837.

${ }^{48}$ Newcastle Chronicle, 11 Mar. 1837.

${ }^{49}$ Letter to the Guardians of Morpeth Union, 8 Mar. 1837 (Northumberland Record Office, SANT/BEQ/28/1/4/474A).

${ }^{50}$ Newcastle Courant, 24 Mar. 1837.

${ }^{51}$ Newcastle Courant, 31 Mar. 1837; Newcastle Journal, 8 Apr. 1837; Newcastle Chronicle, 8 Apr. 1837.
} 
also offers an insight into his wider political views. Chairing a dinner in honour of Lord Leveson, Northumberland's new M.P., Blakey proposed a series of toasts. After toasts to Victoria and the royal family, Blakey proposed 'the people, the legitimate source of all authority and power,' and 'the Liberty of the Press'. ${ }^{52}$ Particularly notable is Blakey's willingness to toast the monarchy. As he elsewhere favourably discusses Louis-Philippe, and sought patronage from both Leopold I and Prince Albert, the indication is that he was amenable to a constitutional monarchy. Of his favourite political theorists, this places Blakey within the traditions of Locke and Montesquieu, who favoured a constitutional monarchy, rather than the republican Paine or proto-anarchist Godwin, and suggests that he was a reformer, rather than a revolutionary.

After his term of office came to an end, Blakey continued to press for poor law reform. He spoke at a demonstration against the poor law in Newcastle, and published Cottage Politics, which made effective use of woodcut illustrations, a device that would distinguish the Northern Liberator from its contemporaries. ${ }^{53}$ The Liberator had only begun circulating in October 1837, just before Blakey left office. Originally owned by wealthy Anglo-American Augustus Beaumont, the Liberator began as a more moderate vehicle, 'published for the express purpose of maintaining pure democracy in the North of England' ${ }^{54}$ Beaumont was unable to stay in Newcastle to supervise publication, and sold to Blakey and Thomas Doubleday, who assumed proprietorship in February 1838. The pair marked their takeover with a new mission statement indicating the radical, democratic approach the Liberator was to take. It was 'a Newspaper established expressly

\footnotetext{
${ }^{52}$ Newcastle Courant, 8 Sept. 1837.

${ }^{53}$ Northern Liberator, 23 Dec. 1837; Elaine Hadley, Melodramatic Tactics: Theatricalized Dissent in the English Marketplace (Stanford, CA: Stanford University Press, 1994), 104.

${ }^{54}$ Brake, Demoor, and Beetham, Dictionary of Nineteenth-century Journalism, 458; Northern Liberator, 21 Oct. 1837.
} 
to advocate the cause of the Industrious, or in plainer terms, the Working Classes; or the most compendious term of all, The People. ${ }^{55}$ Blakey and Doubleday had discussed operating a radically-inclined newspaper championing electoral reform as early as 1835 , so the purchase of the Liberator was the fulfilment of a long-standing ambition. ${ }^{56}$ Irish journalist Thomas Ainge Devyr was appointed to the editing team, and the Liberator quickly became successful. It attracted substantial advertising revenue, unusual among the radical press, and claimed a circulation of 4,000 , which was greater than that of many mainstream Newcastle papers such as the Courant. ${ }^{57}$ Indeed, the Liberator was so successful that it was able to absorb a failing London paper, the Champion. ${ }^{58}$ Although his business-sense proved invaluable in keeping the Liberator profitable, Blakey appears not to have exercised particularly close control over its output as Doubleday and Devyr undertook much of the writing. ${ }^{59}$ The Liberator thus cannot be seen simply as a mouthpiece for Blakey's politics; however, it is not the case that his concern was purely commercial. Certainly, he was not averse to using the Liberator's advertising space to promote his own publications, rooms to rent on his property, or the Britannia Life Assurance Company, for which he was the Newcastle agent. ${ }^{60}$ Nevertheless, Blakey also used the Liberator to champion local political issues. One of he and Doubleday's first actions after assuming ownership was to announce the formation of a joint-stock company to fund a working men's hall in Morpeth. ${ }^{61}$ The purchase of the Liberator had come at an auspicious time for radicalism, particularly in the north. Agitation for working-class

\footnotetext{
${ }^{55}$ Northern Liberator, 10 Feb. 1837.

${ }^{56}$ Blakey, Memoirs, 59.

${ }^{57}$ Brake, Demoor, and Beetham, Dictionary of Nineteenth-century Journalism, 458.

${ }^{58}$ Ibid., 60; Blakey, Memoirs, 103-5.

${ }^{59}$ Brake, Demoor, and Beetham, Dictionary of Nineteenth-century Journalism, 60, 178, 458; Dorothy Thompson, The Chartists (Hounslow: Temple Smith, 1984), 54, 165.

${ }^{60}$ Northern Liberator, 30 Jun. 1838, 28 Jul. 1838, 3 Nov. 1838, 24 Nov. 1838.

${ }^{61}$ Northern Liberator, 7 Apr. 1838, 14 Apr. 1838, 21 Apr. 1838, 28 Apr. 1838; Northern Star and Leeds General Advertiser, 7. Apr. 1838, 14 Apr. 1838.
} 
representation had resulted in the demands listed in The People's Charter of 1838, a draft of which appeared in the Liberator. ${ }^{62}$ Many of the concerns it registered, such as universal suffrage and the secret ballot, dovetailed with Blakey's own political desires, and he threw himself, and the Liberator, enthusiastically behind the Chartist cause. The defunct Northern Political Union was resurrected, with Blakey, Doubleday and Devyr all involved on its council, and began championing Chartism at a series of public meetings. ${ }^{63}$ Much of the editorial content promoted Chartist ideas and the paper's illustrations were reproduced as a series of Chartist handbills. ${ }^{64}$

While Blakey keenly supported Chartism's democratic ideals, he, in common with many Chartists, did not view the Charter as an isolated cause. Electoral reform was seen as a panacea to a variety of societal ills that had not been cured by the Great Reform Act. Blakey continued to oppose vigorously another symptom of that malaise, the poor law. As well as attacking it in print, he called several meetings to protest both it and the Morpeth workhouse, and used a speech at Felling Democratic Festival to the same end. ${ }^{65}$ Ultimately, however, popular reform was Blakey's primary focus. His editorials vigorously promoted universal suffrage and dismissed a rejection of compulsory education by Lord Brougham as an attempt to cultivate a system of 'passive obedience and non resistance'. ${ }^{66}$ As popular support for Chartism grew, the rhetoric in the Liberator's editorials became increasingly radical. This culminated in a pair of articles,

\footnotetext{
${ }^{62}$ Northern Liberator, 2 Jun. 1838.

${ }^{63}$ Thompson, Chartists, 165; Dorothy Thompson (ed.), The Early Chartists (London: Macmillan, 1971), 131-4; Thomas Ainge Devyr, The Odd Book of the Nineteenth Century, or 'Chivalry' in Modern Days, a Personal Record of Reform - Chiefly Land Reform, for the Last Fifty Years (Greenpoint, New York: self-published, 1882), 156, 158-9.

${ }^{64}$ Brake, Demoor, and Beetham, Dictionary of nineteenth-century journalism, 458.

${ }^{65}$ Northern Liberator, 2 Feb. 1839, 2 Mar. 1839, 30 Mar. 1839; London Dispatch and People's Political and Social Reformer, 7 Apr. 1839.

${ }^{66}$ F. C. Mather (ed.), Chartism and Society: An Anthology of Documents (London: Holmes and Meier, 1980), 105.
} 
'Appeal to the Middle Classes' and 'Constitutional Arming', for which Blakey was prosecuted under the sedition laws. While Blakey claims authorship of 'Constitutional Arming' in his Memoirs, Devyr claimed to have written 'Appeal to the Middle Classes', which was simply signed 'Northern Political Union'.67 Devyr had been separately arrested for his part in the ongoing Chartist demonstrations outside Newcastle, and Blakey and Doubleday posted his bail, though he soon absconded to America. ${ }^{68}$ Blakey's prosecution came against a backdrop of Chartist rioting, a fact noted by several newspapers in their coverage of his indictment at Newcastle assizes. ${ }^{69}$ However, Blakey was not afforded the opportunity to defend himself in the same dramatic fashion as Wooler and Cobbett. He was bailed and travelled to London, where he took ill, causing the case to be twice adjourned. ${ }^{70}$ Eventually, an uneasy compromise was brooked, with the seditious libel prosecution withdrawn and Blakey bound over to keep the peace for three years, at the cost of $£ 500$. Facing ruin, Blakey sold the Liberator at a loss. ${ }^{71}$

\section{1841-9: A continental sojourn and History of the Philosophy of Mind}

After an abortive bid to launch a London newspaper, Politician, Blakey moved to France in 1841 to pursue his interest in philosophy. ${ }^{72}$ The libraries of northern France and Flanders proved to be a fertile source for Blakey's writing. He procured enough material to publish two books on early Christians, Lives of the Primitive Fathers (1842) and

\footnotetext{
${ }^{67}$ Blakey, Memoirs, 105; Devyr, The Odd Book of the Nineteenth Century, 184; Thompson, Early Chartists, 131-6; Northern Liberator, 21 and 28 Jul. 1839.

${ }^{68}$ Devyr, The Odd Book of the Nineteenth Century, 186-7; Northern Liberator, 3 Aug. 1839.

${ }^{69}$ Northern Liberator, 3 Aug. 1839; Morning Post, 5 Aug. 1839; Brighton Patriot and South of England Free Press, 6 Aug. 1839; Freeman's Journal and Daily Commercial Advertiser, 7 Aug. 1839.

${ }^{70}$ Newcastle Courant, 6 Mar. 1840; Morning Post, 5 Aug. 1840; Standard, 5 Aug. 1840.

${ }^{71}$ Blakey, Memoirs, 105; Northern Star and Leeds General Advertiser, 20 Feb. 1841.

${ }^{72}$ Blakey, Memoirs, 115.
} 
Christian Hermits (1845). ${ }^{73}$ As with Moral Science, these contained brief biographical sketches compiled from other sources; objects of study ranged from Saint Stephen and Justin Martyr to Athanasius. While Moral Science had obscured Blakey's hagiographical approach by weaving a commentary through the biographical studies, in these volumes that approach was laid bare. In particular, Blakey's tendency simply to dismiss those with whose morality or philosophy he disagreed meant that he did not engage with the thought of influential theologians such as Origen or Arius; indeed, his treatment of each was barely a paragraph describing their character, and nothing of their writing. The result of this approach was that neither book was successful, and each garnered little more than a murmur in the press. Without the hoped-for income from his latest publishing venture, Blakey's finances were imperilled. In his Memoirs, Blakey mentions having to sell some of his books and ask for assistance from friends, although he is understandably reticent about applying for aid from the Royal Literary Fund, through which he availed of $£ 225$ between 1846 and $1859 .{ }^{74}$ However, while travelling through France and Belgium, Blakey put his networking ability to good use and managed to make some important friends, such as Octave Delepierre and Sylvain van de Weyer, who would later form part of Belgium's diplomatic mission to London. ${ }^{75} \mathrm{He}$ also met, through a mutual friend, an Englishman, whose name is redacted in the Memoirs, and who engaged Blakey to ghostwrite a history of Charlemagne. ${ }^{76}$ Although the project never came to fruition, the

\footnotetext{
${ }^{73}$ Robert Blakey, Lives of the Primitive Fathers: Being a Faithful History of the Acts and Sufferings of those Eminent Men who Lived in the Early Ages of the Christian Church (London: James Edwards, 1842); idem., Christian Hermits: Or, the Lives of Several Distinguished Solitaries, from the Earliest Ages of the Christian Church, until the Eighth Century, with Extracts from their Literary Remains (London: Batcheller, 1845)

${ }^{74}$ Blakey, Memoirs, 120; 'Mr Robert Blakey (pseudonym: Palmer Hackle)', Archives of the Royal Literary Fund, 1790-1970s (British Library, Loan 96 RLF 1/1144).

${ }^{75}$ H. R. Tedder, 2004, 'Delepierre, Joseph Octave (1802-1879), author and antiquary' Oxford Dictionary of National Biography, 2004, (http://www.oxforddnb.com/view/article/7456) (21 Feb. 2019)

${ }^{76}$ Blakey, Memoirs, 1223.
} 
research Blakey undertook formed the basis of his History of Political Literature. Blakey also met a group of travelling Britons and ghostwrote for them a fishing guide, Hints on Angling (1846), under the pseudonym Palmer Hackle. Finally, however, Blakey had sufficient time and material to compile his longest work, History of the Philosophy of Mind, in 1848. Spread over four volumes, History of the Philosophy of Mind attempted to chart metaphysics and mental philosophy from the pre-Socratics to the nineteenth century. Compared to Blakey's hagiographies, this was moderate success, and its subscribers included leading European royalty: Leopold I, Louis-Philippe, Friedrich Wilhelm IV and Prince Albert all ordered copies. ${ }^{77}$ Blakey had chosen a fortuitous time to publish Philosophy of Mind, for the new Queen's Colleges in Ireland were advertising for professors. He solicited references from his literary and philosophical friends, and submitted them along with Philosophy of Mind, successfully securing the post. ${ }^{78}$

The theological assumptions that underpinned Blakey's thought were most strongly evident in Philosophy of Mind. In his introduction, Blakey argued that the 'religious feeling or sentiment has an inseparable affinity to the true philosophic spirit' ${ }^{79}$ PreChristian authors were reinterpreted to accord with that theology; for instance, the scepticism of Xenophanes was reinterpreted theologically, as an expression of 'overawe' at the world and recognition of humanity's relative insignificance and inability fully to comprehend it. ${ }^{80}$ Plato was likewise interpreted as a staunch theist, with 'enlarged and refined conceptions of a first universal cause, and of a divine providence', and to which

\footnotetext{
${ }^{77}$ Ibid., 118.

${ }^{78}$ Northern Whig, 7 Aug. 1849, Banner of Ulster, 28 Aug. 1849; Caledonian Mercury, 9 Aug. 1849; Caledonian Mercury, 9 Aug. 1849; York Herald and General Advertiser, 25 Aug 1849.

${ }^{79}$ Robert Blakey, History of the Philosophy of Mind: Embracing the Options of All Writers on Mental Sciences from the Earliest Period to the Present Time, 4 vols, (London: Saunders, 1848), $1: 6$.

${ }^{80}$ Ibid., 25.
} 
Blakey attributed much of the Athenian's success as a philosopher. ${ }^{81}$ For the Alexandrian School, which fused theology and philosophy, special praise was reserved: it was 'inseparably connected with the greatest event this world ever witnessed; the rise and progress of that Christian system' ${ }^{82}$ Early Christian philosophers and their faith were also credited with rescuing humanity from scepticism, which Blakey considered an 'intellectual disease' ${ }^{83}$

Blakey's treatment of early Christian philosophers stands in stark contrast to that afforded to some later heterodox thinkers. Spinoza's writings, according to Blakey, displayed only 'an average share of talent', and were designed to mislead the reader and produce 'injurious consequences on their moral, intellectual, and religious welfare' ${ }^{84}$ Georg Wilhelm Friedrich Hegel was similarly disregarded. Hegel, Blakey insisted, 'despised alike the authority of heaven, the authority of men, and the authority of common sense' ${ }^{85}$ Hegel's sophisticated metaphysics were so absurd, according to Blakey, that it was 'discreditable to the human understanding that it should be tolerated in any community where learning and talents are cultivated', ${ }^{86}$ although given his rather shallow treatment of them, it seems unlikely that Blakey truly grasped the meaning of what Hegel described as 'contradictions'. Blakey's own Calvinist intellectual heritage is also woven through the narrative. Blakey notes that Calvin opposed Zwingli's idea of removing philosophy from education on the grounds that it not only fostered correct understanding of doctrine, but also guarded against heresy. ${ }^{87}$ To reinforce this argument, Blakey pointed to John

\footnotetext{
${ }^{81}$ Ibid., 60 .

${ }^{82}$ Ibid., 154.

${ }^{83}$ Ibid., $150,313$.

${ }^{84}$ Blakey, Philosophy of mind, 1:381, 363.

${ }^{85}$ Blakey, Philosophy of mind, 4:150.

${ }^{86}$ Ibid., 153.

${ }^{87}$ Blakey, Philosophy of mind, 2:130.
} 
Knox, who strongly advocated philosophical inquiry as a crucial part of theological teaching, and the Church of Scotland, which required of candidates for its ministry 'a considerable acquaintance with the philosophy of mind, in all its various ramifications' ${ }^{88}$

In his earlier writing, Blakey had made clear that the question of free will was not merely a metaphysical issue; rather, it was a necessary condition for moral agency, the 'key-stone to every system of morals' ${ }^{89}$ Blakey had a strongly libertarian account of free will, rejecting the possibility of compatibilism by arguing that there was 'no middle course to steer', and dismissing Stoic attempts to reconcile the two as 'fruitless' ${ }^{90}$ This informed his discussion of other thinkers. The Alexandrian School's own libertarian position garnered praise, while Spinoza's determinism was used to accuse him of impiety: '[t]here can be no right conceptions of a Deity, where personality and freedom of action are denied'. ${ }^{91}$ Similarly, the encyclopaedist Denis Diderot's lack of belief in free will was criticised as exemplifying his atheism. ${ }^{92}$ By contrast, Kant was praised for recognising the importance of free will and duties, which coincided with Blakey's own view that religion was 'a system of duties and obligations, and of rewards and punishments' ${ }^{93}$

The links between philosophy and theology were not the only theme that reflected Blakey's own philosophical commitments; his admiration for Common Sense direct realism was evident throughout his work, and most especially Philosophy of Mind. Common Sense was the dominant school in Scottish thought in the early nineteenth century, and exerted considerable influence over the rest of the Anglophone world, as

\footnotetext{
${ }^{88}$ Ibid., 131.

${ }^{89}$ Blakey, Freedom of the Divine and Human Will, 5.

${ }^{90}$ Ibid., 10-11.; idem., Philosophy of Mind, 1:134-5.

${ }^{91}$ Blakey, Philosophy of Mind, 1:159; idem., Philosophy of Mind, 2:369.

${ }^{92}$ Blakey, Philosophy of Mind, 3:144.

${ }^{93}$ Blakey, Philosophy of Mind, 1:318.
} 
well as continental Europe. In Blakey's formative years, the most prominent philosophers of this school were Thomas Brown, Dugald Stewart and William Hamilton, although it had first emerged in the writings of Thomas Reid as a response to the scepticism of David Hume, and would be later popularized by James McCosh, Blakey's successor at Belfast. Common Sense sought to retain an empirical approach to mental philosophy, grounded in the inductive logic of Francis Bacon. However, it opposed the scepticism and idealism of British empiricists such as John Locke, George Berkley and Hume. This school of thought, broadly speaking, held that only sensory experience was a reliable source of human knowledge, rejected the possibility of innate ideas, and contended that there were no rational grounds for belief in an external world. Common Sense, by contrast, posited that all humans directly perceive a mind-independent external reality, through use of inbuilt faculties ('common sense') which are immune to sceptical attack. As it relied on commonly held intuitions, Common Sense also tended to prefer robust pragmatism to abstruse speculation in metaphysics. ${ }^{94}$

Blakey was introduced to Common Sense through David Paterson, his minister at Alnwick, with whom he co-authored a biography of the poet James Beattie. ${ }^{95}$ Paterson had been taught by Dugald Stewart, and introduced he and Blakey; Stewart in turn introduced Blakey to Thomas Brown. Blakey noted that the experience of conversing with Stewart and Brown 'greatly animated' him in the pursuit of his 'own speculations'

\footnotetext{
${ }^{94}$ Alexander Broadie, A History of Scottish Philosophy (Edinburgh: Edinburgh University Press, 2010), 3-4; J. D. Hoeveler, James McCosh and the Scottish Intellectual Tradition from Glasgow to Princeton (Princeton, NJ: Princeton University Press, 1981); D. N. Livingstone, 'James McCosh and the Scottish Intellectual Tradition', in Alvin Jackson and D. N. Livingstone (eds) Queen's Thinkers: Essays on the Intellectual Heritage of a University (Belfast: Blackstaff, 2008), 19-30.

${ }^{95}$ Blakey, Memoirs, 50.
} 
on moral and mental philosophy. ${ }^{96}$ Blakey's treatment of the Common Sense school is noticeably more favourable than that of other intellectual traditions. He quoted frequently from members, particularly Stewart, although Blakey noted that the Scot preferred to use 'the fundamental laws of human belief' rather than 'common sense' in his terminology. ${ }^{97}$ Appeals to 'common sense' and 'popular opinion' abound in Blakey's work, and are considered as being philosophically sound in their own right. ${ }^{98}$ Similarly, in Philosophy of Mind, common sense, whether as a concept or school of thought, was frequently referenced: a total of 125 times across the four volumes. The metaphysics of Parmenides Blakey construed as an early example of what would become Common Sense, as he did the teachings of the Stoic school. ${ }^{99}$ Indeed, Blakey could well have been quoting Reid when he explained Stoic epistemology: 'If your system be against common sense, it must be erroneous; we may not perhaps be able to rebut all your refined and subtile arguments, but be you assured, that nature has not left the first principles of speculation and action to be trifled with by the weak and puny sophistry of man. ${ }^{, 100}$ Blakey often applied this line of reasoning himself, such as his rejection of Nicolas Malebranche's occasionalism for clashing 'with the common-sense view which all mankind entertain of the Divine nature and government, and the free will of man'. ${ }^{101}$

Particularly noteworthy is Blakey's attempt to place himself inside an intellectual tradition favouring empiricism and induction, and opposed to syllogism, which he suggested includes 'Bacon, Locke, Reid, Campbell and Stewart'. ${ }^{102}$ In his History of Moral Science, the choice of 'moral science' as a title was an attempt to draw a parallel

\footnotetext{
${ }^{96}$ Ibid., Memoirs, 30-31.

${ }^{97}$ Blakey, Philosophy of Mind, 4:4.

${ }^{98}$ Blakey, Freedom of the Divine and Human Will, esp. 12-14, 27, 74, 94, 102, 205.

${ }^{99}$ Blakey, Philosophy of Mind, 1:27-8.

${ }^{100}$ Ibid., 135.

${ }^{101}$ Blakey, Philosophy of Mind, 2:319.

${ }^{102}$ Blakey, Essay on Logic, 158.
} 
between natural philosophy and morality, arguing that both were 'built upon observation and fact'. ${ }^{103}$ This wedding of empiricism and morality in fact had its genesis in Hume, but it would not have raised any eyebrows among adherents of the Common Sense tradition. Blakey, then, was broadly sympathetic toward the Common Sense school and in particular its empirical tradition. However, it would be an overstatement to describe Blakey, as Edward Reed does, as simply 'a minor offshoot of the Scottish school, teaching at Belfast'. ${ }^{104}$ Blakey did not wholly subscribe to the tenets of Common Sense, and the major point of departure can be found in their respective treatments of John Locke.

Blakey considered Locke to be the 'Father of the present modern system of British metaphysical philosophy' whose position in metaphysics was analogous to that of Isaac Newton in classical physics, and whose Essay on Human Understanding was 'unquestionably one of the most wonderful books that ever were written on the subject of which it treats' ${ }^{105}$ Such was Blakey's estimation of the Essay that it was one of the few works specifically referred to by him in his memoirs. ${ }^{106}$ Locke received his own chapter in Philosophy of Mind which concluded the second volume, and mental philosophy is clearly considered by Blakey to have pre- and post-Locke eras. Indeed, Blakey insisted that only Descartes came close to Locke's influence. ${ }^{107}$ Blakey frequently discussed philosophers relative to how their views accorded with Locke. Thomas Hobbes, for example, he reinterpreted favourably as having a proto-Lockean conception of empiricism and sensationalism: 'we find the leading maxim of Locke's philosophy clearly and explicitly laid down; namely, that all our ideas are derived through the medium of

\footnotetext{
${ }^{103}$ Blakey, Moral Science, 1:5.

${ }^{104}$ E. S. Reed, From Soul to Mind: The Emergence of Psychology from Erasmus Darwin to William James (New Haven, CT: Yale University Press 1997), 227.

${ }^{105}$ Blakey, Philosophy of Mind, 2:461.

${ }^{106}$ Blakey, Memoirs, 197.

${ }^{107}$ Blakey, Philosophy of Mind, 2:233.
} 
the senses' ${ }^{108}$ Pierre Gassendi he also interpreted as a Lockean, as he 'distinctly declares that we have ideas from the mind's power of reflecting inwardly on its own faculties, which is one of the leading positions of Locke's theory', ${ }^{109}$ although Blakey mistakenly described the Frenchman as an Italian.

Given Blakey's admiration for both Locke and Common Sense, it is unsurprising that he attempted to reconcile the two. He noted that Locke aimed to solve 'all problems on the broad principles of common sense and common reason, arising out of the varied and subtle movements of the reasoning faculty'. ${ }^{110}$ Blakey did criticise some Common Sense interpretations of Locke, such as that of Dugald Stewart, whose system he described as 'no improvement' on that of Locke. ${ }^{111}$ However, Blakey argued that disagreement arose because of how the Common Sense philosophers chose to interpret Locke's use of the word 'idea'. According to Blakey, if 'idea' is used synonymously with 'notion', as Locke suggests in the Essay on Human Understanding, then there could be 'no objection' from the Common Sense school. ${ }^{112}$ Similarly, in a discussion of Thomas Reid, Blakey emphasised that beyond the definition of what constitutes an 'idea', there is little difference between Locke and Reid's theories of mind. While Blakey overstates his case in this regard, in some respects there was a large degree of overlap between their theories, particularly with regard to reflection. As Alexander Broadie points out, 'we find repeatedly that common sense philosophers give considerable weight to the deliverances of consciousness, especially when the deliverances are the product of reflection'. ${ }^{113}$

\footnotetext{
${ }^{108}$ Ibid., 206.

${ }^{109}$ Ibid., 258-9.

${ }^{110}$ Blakey, Sketch of Logic, 271.

${ }^{111}$ Blakey, Moral Science, 1:84, 124-5.

${ }^{112}$ Ibid., 130-2.

${ }^{113}$ Broadie, Scottish Philosophy, 237.
} 
The comparative space given to Blakey's views of morality, Locke, and Common Sense reflect his own interests. However, his narrow frame of reference meant that elsewhere Philosophy of Mind was sorely lacking. Blakey's treatment of some notable philosophers is brief, sometimes no more than a biographical note. Indeed, with four volumes in total, and two chapters on Locke, Blakey's excuse of lacking space is unconvincing. Two thinkers who would dominate Anglophone philosophical discourse in the second half of the nineteenth century, Mill and Hegel, were afforded barely a dozen pages each in Blakey's work, while Arthur Schopenhauer is omitted altogether. Some other writers received disproportionate attention. Blakey's friend Sylvain van de Weyer, received a comparatively lengthy ten pages, despite not producing much original work. ${ }^{114}$ Blakey also made no apology for his disdain toward German metaphysics. In a brief section on Kant, he confessed to being "completely ignorant of the "Critical or Transcendental Philosophy" of Emanuel Kant', and amusingly described the German's impenetrable prose as akin to having its sentences pulled from a bag and arranged at random. ${ }^{115}$ Blakey also readily engaged in ad hominem attacks. David Hume he described as an egotistical controversialist, who wanted 'to endeavour to obtain something which should induce mankind, to the end of time, to admire the subtility and profundity of his genius'. ${ }^{116}$ Voltaire was depicted as a great writer and wit, who was nevertheless 'hasty and superficial' in his metaphysical judgements, glib, and wracked with contradictions. ${ }^{117}$ Meanwhile Hegel, Blakey argued, had 'discovered that distinction and fame were not to be obtained by expounding and propagating other men's opinions; and he consequently

\footnotetext{
${ }^{114}$ Blakey, Philosophy of Mind, 3:99.

${ }^{115}$ Blakey, Moral science, 2:313.

${ }^{116}$ Blakey, Philosophy of mind, 3:139.

${ }^{117}$ Ibid., 259.
} 
bethought himself that something must be done to attract public attention; some new soil must be turned up to secure a rich and fruitful harvest'. ${ }^{118}$

While these defects hampered the chances of Blakey's work becoming a permanent fixture in the history of philosophy they are nevertheless instructive. In many ways, Blakey was emblematic of British thought in the first half of the nineteenth century. As Victor Cousin, professor of philosophy at the Sorbonne, pointed out, philosophy in Britain was dominated by an insularity that matched her geography. ${ }^{119}$ There was a general hostility to abstract metaphysics, and a strong preference for domestic empiricism. Continental thought was treated with mistrust, particularly German idealism, with Hamilton one of barely a handful of philosophers who could even read German. ${ }^{120}$ Blakey's rejection of Kant was therefore understandable; indeed Stewart had done much the same. ${ }^{121}$ Similarly, it was common to dismiss Hegel on theological grounds. Many educated Britons only knew Hegel second-hand, through his association with biblical criticism, and particularly as an influence on David Strauss. ${ }^{122}$ As the British intellectual climate changed in the second half of the nineteenth century, Blakey's philosophy quickly lost relevance. An increased interest in German philosophy and appreciation of biblical criticism led to the translation of several works, such as histories by Kuno Fischer and Friedrich Ueberweg, and Hegel's own writings. English works which seriously discussed German philosophy, such as those by George Henry Lewes and John Daniel Morell, were thus more relevant than Blakey, and were republished several times. That is not to say that Common Sense was entirely supplanted by Idealism, particularly in Belfast: Blakey's

\footnotetext{
${ }^{118}$ Blakey, Philosophy of mind, 4:149.

${ }^{119}$ J. H. Muirhead, 'How Hegel came to England' in Mind 36 (1927): 424.

${ }^{120}$ Ibid., 427; Kirk Willis, 'The Introduction and Critical Reception of Hegelian Thought in Britain 1830-1900', Victorian Studies 32 (1988): 87-8, 97.

${ }^{121}$ Muirhead, 'How Hegel came to England', 425.

${ }^{122}$ Willis, 'Reception of Hegelian thought', 87.
} 
successor at Queen's College, James McCosh, belonged squarely to the former tradition. Nevertheless, the prevailing trend in both British and continental thought was away from Scotland and toward Germany; thus, by the time of his death, Blakey's philosophical works, whatever their merits, were obsolete.

Reviews of Philosophy of Mind were mixed. The Morning Post was generally unimpressed with Blakey's metaphysics and noted his obsession with Locke, while a longer review in The Athenaeum praised its scope, bibliographical utility and ambition, but criticised Blakey's treatment of Hume, and the brevity of some entries. ${ }^{123}$ A review in the Literary Gazette was slightly more favourable. ${ }^{124}$ Most remarkable, however, were the subscriptions obtained. Head of the list was Leopold I, King of the Belgians, and the work had been dedicated, with permission, to Prince Albert, who had also ordered a copy, as had the Prussian King Friedrich Wilhelm IV. ${ }^{125}$ Eventually, Blakey was even able to obtain a subscription from Louis Philippe, King of the French, recognising that such an illustrious list of subscribers would impart his 'work with a certain character of importance and worth'. ${ }^{126}$ After Philosophy of Mind was published, Leopold awarded a medal to Blakey that was reserved for 'great foreign authors'. ${ }^{127}$

Philosophy of Mind has not benefitted from posterity, although some positive reviews do exist. Ironically, in the most popular English translation of Hegel's Philosophie der Weltgeschichte, by John Sibree, the translator's introduction lists Philosophy of Mind as a helpful reference work although given Blakey's commentary on Hegel, and lack of

\footnotetext{
${ }^{123}$ Morning Post, 22 Nov. 1848.; Athenaeum, 24 Feb. 1849, 188-9.

${ }^{124}$ Literary Gazette, 25 Nov. 1848.

${ }^{125}$ Blakey, Memoirs, 118.

${ }^{126}$ Ibid., 119.

${ }^{127}$ Ibid., 119, 240; Newcastle Courant, 13 Jul. 1849.
} 
subsequent mentions, it is unlikely that Sibree found it of much direct use. ${ }^{128}$ Thomas Dixon, mentioning Philosophy of Mind, describes Blakey as 'one of the nineteenth century's leading historians of philosophy'. ${ }^{129}$ Margaret Atherton notes Blakey's inclusion of a section on the relatively obscure Lady Mary Shepherd, ${ }^{130}$ with whom Blakey had corresponded as he admired her work on free-will and causation. ${ }^{131}$ Kirk Willis, by contrast, could praise only Philosophy of Mind's 'monumental' scope. ${ }^{132}$ E. S. Reed's appraisal is that despite it essentially being 'a compendium of brief notes on a plethora of authors' the fourth volume was useful for ascertaining the importance of certain writers in $1850 .{ }^{133}$ However, Howard C. Warren's criticism is perhaps the most piercing, when he suggests that Blakey's treatment of David Hartley 'may be cited as an excellent specimen in every respect of what an historical review should not be'. ${ }^{134}$ No matter its lasting impact, Philosophy of Mind was certainly crucial for Blakey's career; alongside favourable reviews and references, it helped secure Blakey a position as the first Professor of Logic and Metaphysics at Queen's College, Belfast.

\section{Queens College Belfast and History of Political Thought}

Despite winning a prized chair at the new Queen's College, Blakey never taught matriculated students, nor set any examinations. Indeed, Blakey was not overly fond of Ireland, describing Irish life as 'the most striking monument of moral and social

\footnotetext{
${ }^{128}$ G. W. F. Hegel, The Philosophy of History: With Prefaces by Charles Hegel and the Translator, J. Sibree, MA (London: Henry G. Bohn, 1861), vi.

129 Thomas Dixon, From Passions to Emotions: The Creation of a Secular Psychological Category (Cambridge: Cambridge University Press, 2006), 115.; idem., 'The Psychology of the Emotions in Britain and America in the Nineteenth Century: The Role of Religious and Antireligious Commitments', Osiris 16 (2001): 298.

${ }^{130}$ Margaret Atherton, Women Philosophers of the Early Modern Period (Indianapolis: Hackett, 1994), 147.

${ }^{131}$ Blakey, Memoirs, 160-2.

${ }^{132}$ Willis, 'Reception of Hegelian thought', 99.

${ }^{133}$ Reed, Soul to Mind, 226-7.

${ }^{134}$ H. C. Warren, A History of the Association Psychology (New York: Scribner, 1921), 21.
} 
debasement which the world has ever seen since the creation'. ${ }^{135}$ Fellow Presbyterians tended to escape his ire however, since Blakey did praise his friend William Gibson, professor of Christian ethics at Belfast Presbyterian College. ${ }^{136}$ This admiration for Belfast Presbyterians appears to have been reciprocated. The Banner of Ulster, the leading Irish Presbyterian newspaper, approvingly described Blakey as 'an orthodox Presbyterian', reflecting concerns that the new college might harbour advocates of heterodox theology. Belfast's other college, the Royal Belfast Academical Institution, had been embroiled in controversy during the previous decade over its professor of moral philosophy, John Ferrie, and so the religious convictions of the philosophy professors at Queen's were keenly scrutinised. ${ }^{137}$ After his first term, Blakey immediately left for Scotland, where he took an angling holiday. ${ }^{138}$ Citing illness, he did not return to teach after the second term, although he signed the introduction to Historical Sketch of Logic 'Belfast, January 11851 '. ${ }^{139}$ Blakey makes no further mention of Queen's College in the Memoirs; by 8 October, the Revd P. Shuldman Henry, President of Queen's College, had written to Lord Clarendon, Lord Lieutenant of Ireland, to have Blakey dismissed for continued absence. ${ }^{140}$ Divested of his academic wage, Blakey returned to writing. He released a series of books on angling, covering England (1853), Scotland (1854), and fishing songs (Angler's Song Book, 1855). This provided a modest income while he reworked his notes from the abortive Charlemagne project into the History of Political

\footnotetext{
${ }^{135}$ Blakey, Memoirs, 196.

${ }^{136}$ Ibid; A. R. Holmes, The Irish Presbyterian Mind: Conservative Theology, Evangelical Experience, and Modern Criticism, 1830-1930 (Oxford: Oxford University Press, 2018), 33.

${ }^{137}$ Banner of Ulster, 28 Aug. 1849; A. R. Holmes, 'From Francis Hutcheson to James McCosh: Irish Presbyterians and Defining the Scottish Philosophy in the Nineteenth Century', History of European Ideas 40 (2014): 622-43.

${ }^{138}$ Blakey, Memoirs, 200.

${ }^{139}$ T. W. Moody and J. C. Beckett, Queen's, Belfast 1845-1949: The History of a University, 2 vols, (London: Faber and Faber, 1959), 1:161; Robert Blakey, Historical Sketch of Logic, from the Earliest Times to the Present day (London: Ballière, 1851), ix.

${ }^{140}$ Letter from Lord Clarendon, 8 Oct. 1851 (The National Archives, HO 45/3954).
} 
Literature (1855). A groundbreaking attempt to document the history of political thought, this was to be Blakey's last academic work.

The History of Political Literature was something of a first, as never before had a concerted attempt been made to chart the history of political thought. Indeed, several commentators have indicated that it was the 'first genuine textbook' of political thought 'as a disciplinary genre'. ${ }^{141}$ Blakey's introduction indicates that he retained much of his earlier views. In particular, he argued for mass education being essential to political empowerment; similarly, much of Blakey's analysis is framed as a discourse on liberty and tyranny. ${ }^{142}$ Although Blakey claimed to avoid partisanship in the work, his political inclinations were strongly evident: his discussions on liberty he described as 'timeless truths,' and made frequent references to the underlying morality of political issues and to theological concerns. ${ }^{143}$

History of Political Literature was the first serious attempt to distil and codify the history of political thought; Blakey can thus lay claim to being the first serious historian of political thought. What is particularly remarkable, however, is that Blakey's approach and framework have survived to the present day with only relatively minor changes. Blakey felt that 'the sacred canon' of Old Testament political writings demanded political instruction of the populace. Blakey's approach was to introduce his own, political, canon. Beginning with the Old Testament, Blakey charted the steady upward march of liberty,

\footnotetext{
${ }^{141}$ Stuurman, 'The Canon of the History of Political Thought', 149; Farr, 'The History of Political Thought as Disciplinary Genre', 226.

${ }^{142}$ Robert Blakey, The history of political literature from the earliest times, 2 vols (London: Richard Bentley, 1855) 1:v-xiii, xvi.

${ }^{143}$ Stuurman, 'The Canon of the History of Political Thought', 52; Boucher and Kelly (eds.), Political thinkers, 7; C. S. McCoy and J. W. Baker, Fountainhead of Federalism: Heinrich Bullinger and the Covenantal Tradition (Louisville, Westminster/John Knox Press:1991), 46.
} 
through Egypt, Greece, Rome, Charlemagne, and through to the Enlightenment, based around the works of key authors. Interestingly, while Blakey had two further volumes in manuscript, which discussed the eighteenth and nineteenth century, these were never published. However, these would not dramatically alter the fundamental narrative already told; the triumph of liberty and rationalism was inevitable, and the following centuries were merely a case of extending this progress. This is, of course, a familiar criticism; the perils of Whiggish history are a commonplace. While Blakey saw himself as a Radical rather than a Whig, the narrative process is almost identical, and the modern, liberal, canon is still incredibly similar. Indeed, there are some instances in which History of Political Literature comes very close to Blakey's earlier hagiographies. The reverence with which Blakey treats some thinkers, such as John Locke, makes clear who he believed were the patron saints of liberty. Indeed, Locke's canonisation by Blakey is particularly striking. According to Blakey, Locke's 'method of reasoning is so conclusive, and his judgement so profound and correct' that his Treatise on Government will inevitably underpin the government of any state with 'any degree of legislative intelligence and liberty'. ${ }^{144}$ Other thinkers were frequently compared to Locke, anachronistically agreeing or disagreeing with his views, while legal systems such as the Roman code of laws were analysed from a Lockean perspective. ${ }^{145}$ For Blakey, then, Locke embodied an idealised representation of liberal political values, timeless truths that his narrative was to reveal. However, as Siep Stuurman has argued, there is an inherent contradiction in attempting to 'collapse history and a timeless canon into each other.' ${ }^{146}$ Arguments presented as supposedly timeless truths in fact arose as part of ongoing debates within a specific historical context. Divested of this context, they are made to function merely as pieces of

\footnotetext{
${ }^{144}$ Blakey, History of Political Literature, 2:166.

${ }^{145}$ Blakey, History of Political Literature, 1:188

${ }^{146}$ Stuurman, 'The Canon of the History of Political Thought', 152.
} 
an ahistorical narrative. Quentin Skinner, reflecting on an edition of Locke's Two Treatises of Government by Peter Laslett, points out that even this 'classic defence of contractarianism' can only truly be understood as 'an intervention in a particular crisis... from an identifiable position on the spectrum of political debate in the early 1680 s. $^{, 147}$

Blakey's lengthy treatment of Locke, in addition to the observations woven approvingly throughout his narrative, reflected the esteem in which he held the philosopher. However, discussion of similarly prominent political philosophers, such as Hobbes and Machiavelli, was rather less enthusiastic. Each received barely two pages, just long enough for Blakey to dismiss them as confused and immoral. Pufendorf and Spinoza, meanwhile, each merited four pages. By contrast, dozens of pages were spent discussing the work of John Milton, the favourite author of Blakey's artisan colleagues Robert Dunn and Thomas Hall. Indeed, the amount of space devoted to British authors was remarkable; almost as many pages as those of every other country combined.

The History of Political Literature was fairly well received; most reviews were generous and Blakey's even-handed treatment of some thinkers was praised. ${ }^{148}$ However, it was not without its critics: William A. Dunning, a professor at Columbia University who later compiled a similar work, dismissed it as 'crude, scrappy and superficial' ${ }^{149}$ Nevertheless, it is fair to regard the work as a qualified success. While History of Political Literature was not without fault, due to its scope and the brevity of some entries, political theory became a discipline in its own right, and Blakey had established both a framework and

\footnotetext{
${ }^{147}$ Quentin Skinner, Liberty Before Liberalism (Cambridge: Cambridge University Press, 2012), 103.

${ }^{148}$ The Friend of India, 19 Jul. 1855; Athenaeum, 28 Apr. 1855; Literary Gazette, 20 Jan. 1855.

${ }^{149}$ Farr, 'The History of Political Thought as Disciplinary Genre', 233.
} 
canon which remain largely unchanged today. ${ }^{150}$ History of Political Literature was reprinted several times, including an edition as late as 1970, and was considered sufficiently weighty to be included in a list of standard works on political economy for the library of the London Statistical Society in 1865 , where it sat alongside works by Gladstone, Mill, and Smith. ${ }^{151}$ Blakey, since his years in Alnwick, strove to be included among the political and literary heavyweights of his time; with his final academic work, he came close to achieving that goal.

For Blakey, the timeless truth of liberalism was that its apotheosis was found in Locke. From the Romans anticipating Locke, those other thinkers given more than an encyclopedic entry were, with rare exception, interesting only in so far as they engaged with the spectrum of Locke's writings. Yet to focus so heavily on a Lockean concept of liberalism, and to lionise its author for his moral righteousness, fails to account for the wider context in which such debates occurred, privileges the contributions of certain figures, and reduces the complex web of historical political discourse to a morality tale. Although modern textbooks of political thought have refined this approach, the rough framework still persists, and the impression remains that certain authoritative arguments, concepts, and voices existed in a vacuum, rather than changing and developing over time. This is not entirely Blakey's responsibility; nevertheless, his role, and the sequence of

\footnotetext{
${ }^{150}$ Stuurman, 'The Canon of the History of Political Thought', 150; Boucher and Kelly, Political Thinkers, $3,5$.

${ }^{151}$ Robert Blakey, The History of Political Literature from the Earliest Times (Port Washington, NY: Kennicat, 1970); 'Report of the Council for the Financial Year Ended 31st December, 1864, and for the Sessional Year Ended 15th March, 1865', Journal of the Statistical Society of London 28 (1865): 237.
} 
events that led to a provincial artisan writing the first history of political thought, is surely remarkable.

Study of these events illustrates how Blakey's informal education was not a barrier to his intellectual development. While his eventual position as a professor of logic and metaphysics was an atypical outcome given his circumstances, Blakey's career illustrates the vibrant intellectual cultures of both British Presbyterianism and her labouring classes. Further, it demonstrates that it was possible for someone raised in such a culture to be successful in academia. Blakey's political career offers an insight into the composition of political radicals, the existence of a politically aware and literate artisan class, who provided a receptive audience for radical newspapers as long as their message was packaged appropriately. It also illustrates the major political demands of radicals during this period: repeal of the New Poor Law, as well as electoral reform generally and universal suffrage specifically. Blakey's libel case and subsequent withdrawal from frontline politics demonstrates the difficulties encountered by democratising movements, and the power available to the government in the sedition laws.

Finally, History of Political Literature also illustrates a market for new intellectual disciplines, and an increased academic desire to rigorously compile, catalogue and explain the social sciences. Blakey's philosophical career exemplifies several key themes. It highlights the serious moral and religious undercurrent to British thought. It also highlights the two competing ideas that shaped much British philosophy in the preceding century, Common Sense and idealism. Blakey's efforts to resolve these are particularly notable, as they highlight the conflict within British philosophy during the nineteenth century. In particular, they help to explain the decline in popularity of Scottish philsophy 
over the course of the nineteenth century as a result of what Gordon Graham has called its 'fatal ambiguity'. ${ }^{152}$. Locke was venerated for his liberal political philosophy, yet his idealist epistemology clashed with the realist account of the Common Sense school. Blakey's commitment to Common Sense, and its deep roots in his Presbyterian upbringing, was as enduring as his admiration for Locke. Since he was unwilling to abandon Common Sense, nor restrict his beatification of Locke as merely a political philosopher, Blakey was forced to use semantics to reconcile the two and provide a satisfactory account of knowledge. Blakey also exemplifies the initially hostile reception that German idealism received, and its tendency to be dismissed out of hand, mainly as a result of the two preceding themes. Finally, there is evidence of the changing environment of British philosophy as the nineteenth century progressed: the increased appetite for histories of philosophy, although, crucially, not Blakey's, and the increasing receptiveness toward German thought.

152 Gordon Graham, 'The nineteenth-century aftermath' in Alexander Broadie (ed.) The Cambridge Companion to the Scottish Enlightenment (Cambridge, Cambridge University Press:2003), 347. 


\section{Bibliography}

Atherton, Margaret, Women Philosophers of the Early Modern Period. Indianapolis: Hackett, 1994.

Blakey, Robert, An Essay Shewing the Intimate Connexion between our Notions of Moral Good and Evil, and our Conceptions of the Freedom of the Divine and Human Will. Edinburgh: Adam Black, 1831.

Blakey, Robert, History of Moral Science, 2 vols. Edinburgh: James Duncan, 1833-6.

Blakey, Robert, An Essay Towards an Easy and Useful System of Logic. Edinburgh: James Duncan, 1834.

Blakey, Robert, Letter to the Guardians of Morpeth Union. 8 Mar. 1837. SANT/BEQ/28/1/4/474A. Northumberland Record Office, Ashington.

Blakey, Robert, Lives of the Primitive Fathers: Being a Faithful History of the Acts and Sufferings of those Eminent Men who Lived in the Early Ages of the Christian Church. London: James Edwards, 1842.

Blakey, Robert, Christian Hermits: Or, the Lives of Several Distinguished Solitaries, from the Earliest Ages of the Christian Church, until the Eighth Century, with Extracts from their Literary Remains. London: Batcheller, 1845.

Blakey, Robert. History of the Philosophy of Mind: Embracing the Options of All Writers on Mental Sciences from the Earliest Period to the Present Time, 4 vols. London: Saunders, 1848.

Blakey, Robert, Historical Sketch of Logic, from the Earliest Times to the Present Day. London: Ballière, 1851.

Blakey, Robert, The history of political literature from the earliest times, 2 vols. London: Richard Bentley, 1855.

Blakey, Robert, Memoirs of Dr. Robert Blakey: Professor of Logic and Metaphysics, Queen's College, Belfast, edited by Henry Miller. London: Trübner, 1879.

Blakey, Robert, The History of Political Literature from the Earliest Times. Port Washington, NY: Kennicat, 1970.

Boucher, David, and Paul Kelly. Political Thinkers: From Socrates to the Present, 2nd ed. Oxford: Oxford University Press, 2009.

Brake, Laurel, Marysa Demoor, and Margaret Beetham (eds.), Dictionary of NineteenthCentury Journalism in Great Britain and Ireland. London: Academia Press and the British Library, 2009.

Broadie, Alexander, A History of Scottish Philosophy. Edinburgh: Edinburgh University Press, 2010. 
Chase, Malcolm, Chartism: A New Histoy. Manchester: Manchester University Press, 2007.

Cobbett, William, Cobbett's Tour in Scotland, and in the Four Northern Counties of England: in the Autumn of the Year 1832. London: Mills, Jowett, and Mills, 1833.

Devyr, Thomas Ainge, The Odd Book of the Nineteenth Century, or 'Chivalry' in Modern Days, a Personal Record of Reform - Chiefly Land Reform, for the Last Fifty Years. Greenpoint, New York: self-published, 1882.

Dixon, Thomas, 'The Psychology of the Emotions in Britain and America in the Nineteenth Century: The Role of Religious and Antireligious Commitments', Osiris 16, (2001): 288-320.

Dixon, Thomas, From Passions to Emotions: The Creation of a Secular Psychological Category. Cambridge: Cambridge University Press, 2006.

Elliot, K, 'Fishing Lines: Hooked on Musical Bait', Independent, 25 Sept. 1994.

Farr, James, 'The History of Political Thought as Disciplinary Genre' in The Oxford Handbook of Political Theory, edited by John S, Dryzek, S., Bonnie Honig, and Anne Phillips, 225-42. Oxford: Oxford University Press, 2006.

Graham, Gordon, 'The nineteenth-century aftermath' in The Cambridge Companion to the Scottish Enlightenment, edited by Alexander Broadie, 338-50. Cambridge: Cambridge University Press, 2003.

Hadley, Elaine, Melodramatic Tactics: Theatricalized Dissent in the English Marketplace. Stanford, CA: Stanford University Press, 1994.

Hawkins, Roger, 2008, 'Blakey, Robert [pseud. Palmer Hackle] (1795-1878), radical and historian of philosophy, Oxford Dictionary of National Biography. (https://doi.org/10.1093/odnb/9780192683120.013.2595).

Hegel, G. W. F., The Philosophy of History: With Prefaces by Charles Hegel and the Translator, J. Sibree, MA. London: Henry G. Bohn, 1861.

Hoeveler, J. D., James McCosh and the Scottish Intellectual Tradition from Glasgow to Princeton. Princeton, NJ: Princeton University press, 1981.

Holmes, A. R., 'From Francis Hutcheson to James McCosh: Irish Presbyterians and Defining the Scottish Philosophy in the Nineteenth Century', History of European Ideas 40 (2014): 622-43.

Holmes, A. R., The Irish Presbyterian Mind: Conservative Theology, Evangelical Experience, and Modern Criticism, 1830-1930. Oxford: Oxford University Press, 2018.

Home Office Registered Papers, Ireland: Universities, c1841-1855, 1856-1871. HO 45/3954, The National Archives, Kew. 
Kelly, Paul 'Contextual and Non-Contextual Histories of Political Thought', in The British Study of Politics in the Twentieth Century, edited by Jack Hayward, Brian Barry and Archie Brown, 37-61. Oxford: Oxford University Press, 2003.

Kelly, Thomas, George Birkbeck: Pioneer of Adult Education. Liverpool: Liverpool University Press, 1957.

Livingstone, D. N. 'James McCosh and the Scottish Intellectual Tradition' in Queen's Thinkers: Essays on the Intellectual Heritage of a University, edited by Alvin Jackson and D. N. Livingstone, 19-30. Belfast: Blackstaff, 2008.

Mather, F. C. (ed.), Chartism and Society: An Anthology of Documents. London: Holmes and Meier, 1980.

McCoy, C. S., and J. W. Baker, Fountainhead of Federalism: Heinrich Bullinger and the Covenantal Tradition. Louisville: Westminster/John Knox Press, 1991.

Moody, T. W., and J. C. Beckett, Queen's, Belfast 1845-1949: The History of a University, 2 vols. London: Faber and Faber, 1959.

Muirhead, J. H., 'How Hegel came to England' in Mind 36 (1927): 423-47.

Editorial, The Northern tribune: a periodical for the people 1, (Nov. 1854): 324-5.

Prothero, Iorweth, Artisans and Politics in Early Nineteenth-Century London: John Gast and his Times. London: Dawson, 1979.

Reed, E. S., From Soul to Mind: The Emergence of Psychology from Erasmus Darwin to William James. New Haven, CT: Yale University Press 1997.

'Report of the Council for the Financial Year Ended 31st December, 1864, and for the Sessional Year Ended 15th March, 1865', Journal of the Statistical Society of London 28 (1865).

Rose, Jonathan. The Intellectual Life of the British Working Classes. New Haven, CT: Yale University Press, 2010.

Royal Literary Fund Case Files. Loan 96 RLF 1/1144. British Library, London.

Sambrook, James, William Cobbett. London: Routledge, 1973.

Shubert, Adrian, 'Private Initiative in Law Enforcement: Associations for the Prosecution of Felons, 1744-1856' in Policing and Punishment in Nineteenth Century Britain, edited by Victor Bailey, 25-41. London: Crook Helm, 1981.

Skinner, Quentin, Liberty before Liberalism. Cambridge: Cambridge University Press, 2012.

Leslie Stephens (ed.), Dictionary of National Biography, 14 vols. London: Smith, Elder, \& Co., 1885-1900. 
Stuurman, Siep. 'The Canon of the History of Political Thought: Its Critique and a Proposed Alternative', History and Theory 39, no. 2 (2000): 147-66.

Tedder, H. R. 2004, 'Delepierre, Joseph Octave (1802-1879), author and antiquary' Oxford Dictionary of National Biography (http://www.oxforddnb.com/view/article/7456).

The Objects and Rules of the Northern Political Union: Passed at a Meeting held in the Music Hall, Newcastle upon Tyne, on Monday, 27th June 1831 with the Declaration of the Council of the Union. (Newcastle, 1831).

Thompson, Dorothy, The Chartists. Hounslow: Temple Smith, 1984.

Thompson, Dorothy, The Early Chartists. London: Macmillan, 1971.

Vincent, Andrew. The Nature of Political Theory. Oxford: Oxford University Press, 2007.

Warren, H. C., A History of the Association Psychology. New York: Scribner, 1921.

Willis, Kirk, 'The Introduction and Critical Reception of Hegelian Thought in Britain 1830-1900’, Victorian Studies 32, (1988): 85-111. 